\title{
Distortions and Deformations of Metaled Meso-Substituted and Unsubstituted Porphyrins and Derivatives in Crystal Structures
}

\author{
Philippe V. Tsalu1, Tharcisse 0. Monama1,2, Hilaire V. Mambo1, Dorothée D. Tshilanda1, \\ Pius T. Mpiana1, Bodrique M. Nsimba1, Virima Mudogo1, Pitchou N. Bokolombe1, \\ Damien S. T. Tshibangu ${ }^{1}$, Zephyrin G. Yav ${ }^{1}$ \\ ${ }^{1}$ Department of Chemistry, Faculty of Science, University of Kinshasa, Kinshasa, Democratic Republic of the \\ Congo \\ ${ }^{2}$ Departement de Géochimie Appliquée, Centre de Recherches Géologiques et Minières, Kinshasa, Democratic \\ Republic of the Congo \\ Email: philippetsalu@yahoo.fr
}

Received 26 February 2016; accepted 26 February 2016; published 29 February 2016

Copyright (C) 2016 by authors and Scientific Research Publishing Inc.

This work is licensed under the Creative Commons Attribution International License (CC BY).

http://creativecommons.org/licenses/by/4.0/

(c) (i) Open Access

\section{Abstract}

Experimental crystallographic structural parameters of a range of metaled meso-substituted and unsubstituted porphyrins were reviewed to show how far the meso-substitution by any functional group and the insertion of metal in the porphyrins core macrocycle may affect the geometry. The analysis of twists and angles has shown two kinds of distortions: external $\left[\mathrm{T}\left(\mathrm{C}^{\beta}-\mathrm{C}^{\alpha}-\mathrm{C}^{\mathrm{mes}}-\mathrm{X}^{n}\right)\right.$ and $\left.\mathrm{T}\left(\mathrm{C}^{\beta}-\mathrm{C}_{-}{ }_{-} \mathrm{C}^{\text {meso-}} \mathrm{C}^{\alpha}\right)\right]$ and internal $\left[\mathrm{T}\left(\mathrm{N}^{m_{-}} \mathrm{C}^{\alpha_{-}} \mathrm{C}^{\text {meso }}-\mathrm{X}^{n}\right)\right.$ and $\left.\mathrm{T}\left(\mathrm{N}^{n_{-}} \mathrm{C}^{\alpha_{-}} \mathrm{C}^{\text {meso- }} \mathrm{C}^{\alpha}\right)\right]$ with averages of $\left[+6^{\circ}\right.$ and $\left.-6^{\circ}\right]$ and $\left[-5^{\circ}\right.$ and $\left.+5^{\circ}\right]$, respectively.

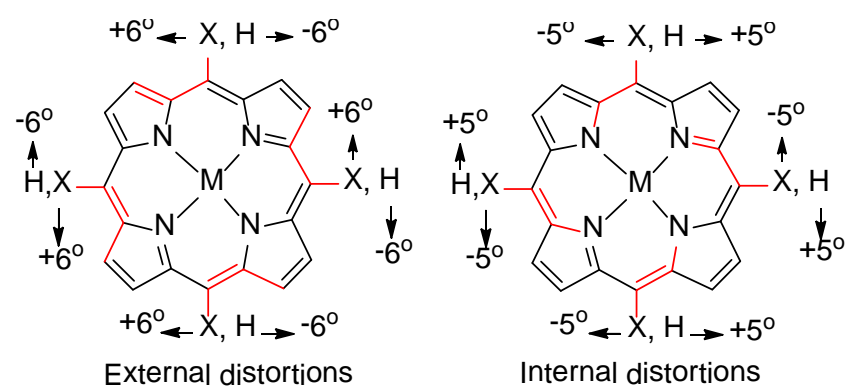

In the meso-substituted case, the external and internal twists $\mathrm{C}^{\beta_{-}} \mathrm{C}^{\alpha-} \mathrm{C}^{\text {meso- }} \mathrm{X}$ and $\mathrm{N}-\mathrm{C}^{\alpha}-\mathrm{Cmeso} \mathrm{X}$, re-

How to cite this paper: Tsalu, P.V., et al. (2016) Distortions and Deformations of Metaled Meso-Substituted and Unsubstituted Porphyrins and Derivatives in Crystal Structures. Crystal Structure Theory and Applications, 5, 1-15.

http://dx.doi.org/10.4236/csta.2016.51001 
spectively are oppositely orientated. Similar effect is observed in meso-unsubstituted of $\mathrm{C}^{\beta}-\mathrm{C}_{-} \alpha_{-}$ $\mathrm{C}^{\text {meso-H }} \mathrm{H}$ and $\mathrm{N}-\mathrm{C}^{\alpha}{ }_{-} \mathrm{C}^{\text {meso-H}}-\mathrm{H}$. However, the external distortions are more significant than internal. Considering the same order, the limit of distortions is $\left[97^{\circ}\right.$ and $\left.132^{\circ}\left(-48^{\circ}\right)\right]$ for external and $\left[91^{\circ}\right.$ $\left(-89^{\circ}\right)$ and $52^{\circ}$ ] for internal. In the two cases, the substituents have opposite directions of distortions. The meso-substituted porphyrins have a high limit of twisting than usubstituted one, depending of the weight of substituents. The average of the bond angular deformations is $168^{\circ}$, almost planar. However, the limit of angular deformation is $94^{\circ}$.

\section{Keywords}

\section{Metaled Meso-Substituted and Unsubstituted Porphyrins and Derivates, Crystals Structures, Distortions and Bonds Angular Deformations}

\section{Introduction}

Porphyrins show much promise in many areas of molecular engineering and have been suggested as building blocks for many diverse applications such as artificial photosynthesis, novel optical materials, and molecular-scale electronics [1] [2]. Their structures contain an aromatic macrocyclic tetrapyrrole (Figure 1) [3], characterized by three kinds of carbon atoms $\alpha, \beta$ and meso. Four fused pyrrole molecules are attached by methenes $(=\mathrm{CH}-)$ considered as meso carbons $(5,10,15$ and 20$)$. The two carbons of each pyrolle cycles attached to nitrogen atom, which bind to the meso carbons are named $\alpha(1,4,6,9,11,14,16$ and 19) and the remaining external carbons of each pyrolle cycles binded to $\alpha$ carbons are named $\beta(2,3,7,8,12,13,17$ and 18). Through metalation, the nitrogens can carry metal atom. In non-metallic porphyrins, two pyrroles carry hydrogen atoms as for $\beta$ carbon atoms in unsubstituted cases [4] [5].

Chemistry of that such metalloporphyrins is controlled by their aromatic character, the complex metal and the kind of peripherally and/or axially fixed substituents. These factors influence the electronic density distribution within the core of the macrocycle and thus determine its reactivity and stability, as well [6]-[8].

Studies on the aromatic rings such as benzene and others have shown that substitution and complexation influence the electronic density and lead to the new properties [9] [10].

Similar studies have shown that the occurring of large substitutes around porphyrins and derivatives such as phenyles in meso positions leads to the loss of their planar structures, so become nonplanar [11]. The four different conformational possibilities are shown in Figure 2 [12] [13].

Owing to the flexibility of the macrocycle, porphyrins have mostly aroused remarkable and extensive interest for many years due to their wideranging applications in photophysics, coordination chemistry, liquid crystals, solar cells, catalysis, photovoltaic devices, photodynamic therapy (PDT) and artificial light harvesting antennas. Structural details are essential to more understand the chemical backgroung of such compounds, especially their solid state. However, most of attempts in order to determine characteristics have been focused on the planarity of the cycles [14] [15]. Thus, few researches had considered the substitution approaches [16] [17]. In addition, most of studies we can find have performed by considering the substituent effects on specific experimental phenomena and generally electronic structure [2] [8] [18] [19]. Crystallographic and molecular studies have been the

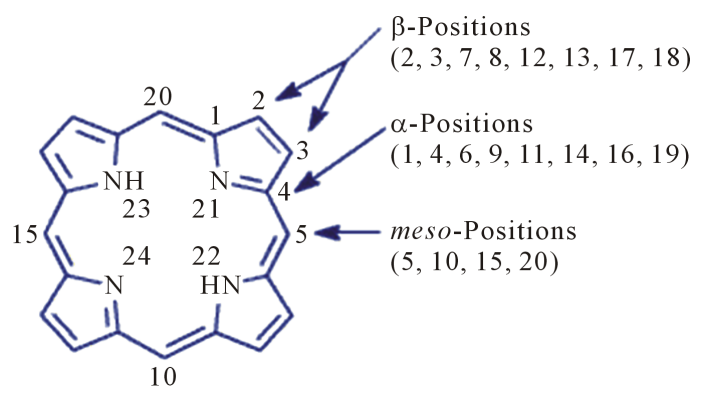

Figure 1. Structure of a porphyrin with UPAC numbering. 


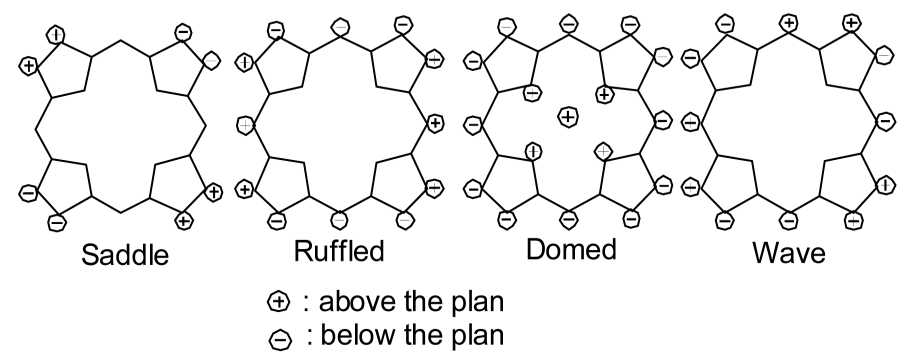

Figure 2. Conformational possibility of porphyrins and derivatives.

most used means in the search for their unique properties [6] [20]. Recently, our team tries to understand the experimental background of the crystallization of porphyrins and derivatives structures, especially those coordinated by iron. The results of such study have shown a relationship between packing and structure deformations. That observation is possible in the group of meso carbons substituted and coordinated metal [7]. In literature, we had not found about a study or a method describing a general view of the geometry of thousands structures of metaled meso-substituted and unsubstituted porphyrins in their known crystal structures. Therefore in this work we use experimental crystallographic structural data from Cambridge Structural Database (CSD) related to the metaled meso-substituted and unsubstituted in order to understand the geometry of this important group in their crystal structures.

\section{Materials and Methods}

\subsection{Cambridge Structural Data Base Software Package}

The Cambridge Structural Database (CSD) is the international standard repository for small-molecule and metal-organic crystal structures and is curated by the Cambridge Crystallographic Data Centre (CCDC) [21] [22]. There are now more than 715,000 structures archived in the CSD. The CSD System incorporates an extensive suite of user-friendly and flexible tools for searching and analyzing this wealth of information [6]. Chemical knowledge extracted from the CSD is applicable to many areas of the chemical and physical sciences, especially pharmaceutical drug discovery, materials design, and drug development and formulation. The CSD is frequently used for statistical analysis of intramolecular and intermolecular geometric structural parameters as well as other data types such as space group, colour, morphology and unitcell dimensions [22] [23].

The software for searching crystal structure knowledge provided by the CCDC, such as ConQuest and Mercury, has been focused on providing sophisticated and flexible tools for crystallographers, structural chemists and the drug design community [24] [25].

Each CSD entry contains the following information (fully described elsewhere): bibliographic, textual, and numerical information, chemical diagram, crystal structure data, filters (secondary search criteria).

Each CSD entry is identified by a unique refcode (entry ID) comprising: six letters, e.g. ABACOF, two digits identifying additional structure determinations, e.g. ABACOF03. The CSD also records a variety of deposition numbers published by many primary journals to identify crystallographic data deposited with the CCDC [26].

The study is semi-empirical (i.e. we use computational tools and study experimental data) and appeal to softwares, especially ConQuest, Mercury and Vista, developed by Cambridge Crystallographic Data Centre (CCDC) for the handling of Cambridge Structural Database [27]-[29].

The 2015 release of the Cambridge Structural Database (CSD version 5.36) containing a total of 717,876 entries was used. ConQuest is firstly used to search all the sample of porphyrins and derivatives structures by defining geometric and chemical parameters such as: refinement parameter $\mathrm{R}$, substitutions, chemical bonds, angles, torsions, plans, unit cells, etc. and secondly to send the structures and data found on CSD to Mercury, the most developed CSD software to calculate parameters and visualizing 3D structures with their crystallographic parameters. The numerical data from CSD are also sent to Vista a CSD statistical data analysis software, where statistical calculations and graphics are made. In each case, all structural data related to the sample of porphyrins and derivatives from CSD are correlated in order to show the relative importance of each parameter on the refinement parameters and structures [24] [26]. 


\subsection{Refinement Parameter}

The agreement of observed and calculated structure factors is often measured with the traditional R-factor [30].

$$
R=\frac{\sum_{\mathrm{H}}|| F_{0}|-| F_{C}||}{\sum_{\mathrm{H}}\left|F_{0}\right|}
$$

where $F_{0}$ and $F_{C}$ correspond to experimental and calculated factors of structure, respectively, and are evaluated by:

$$
F_{h k l}=\int_{x} \int_{y} \int_{Z} \rho(X, Y, Z) \exp [2 \pi i(h x+k y+l z)] \mathrm{d} x \mathrm{~d} y \mathrm{~d} z
$$

which is the Fourier transformed of the electronic density of all atoms in the units cells given by:

$$
\rho(x, y, z)=\frac{1}{V} \sum_{h} \sum_{k} \sum_{l} F_{h k l} \exp [-2 \pi i(h x+k y+l z)]
$$

where $(x, y, z)$ : position of each atom into the unit cell, $V$ : volume of the unit cell, $(h k l)$ : reflexion plans of X-ray beam in the unit cell. The factor of structure $F_{h k l}$ is the amplitude of diffusion of X-ray in the unit cell and each unit cell intervenes in the diffusion of the crystal. So the accurate accepted values during structure resolution are those of $\mathrm{R}<0.1$ or $10 \%$ The relative qualities of structures are, R: $1 \%-3 \%$ : Exceptional, $3 \%$ - 4\%: Very high, 4\% - 5\%: High, 5\% - 7\%: Good, 7\% - 9\%: Mean, 9\% - 10\%: Enough, 10\% - 15\%: Poor, > 0.15 Wrong [7]. Thus, for a big population of porphyrins the refinment is calculated as $\mathrm{R}=$ Mean \pm Std. Dev.

\section{Results and Discussions}

\subsection{Crystal Structures Distributions of Porphyrins and Derivatives: Refinement Parameter R Analysis}

The analysis of 717,876 crystalline structures from CSD solved by single crystal X-ray diffraction permitted to list a total of 5794 structures of porphyrins and derivatives or $0.81 \%$ entry. From this we can notice the relatively weak rate of porphyrins structures and their corresponding derivatives. Figure 3 shows the histogram of distribution of all the 5794 structures of porphyrins versus their refinement parameters.

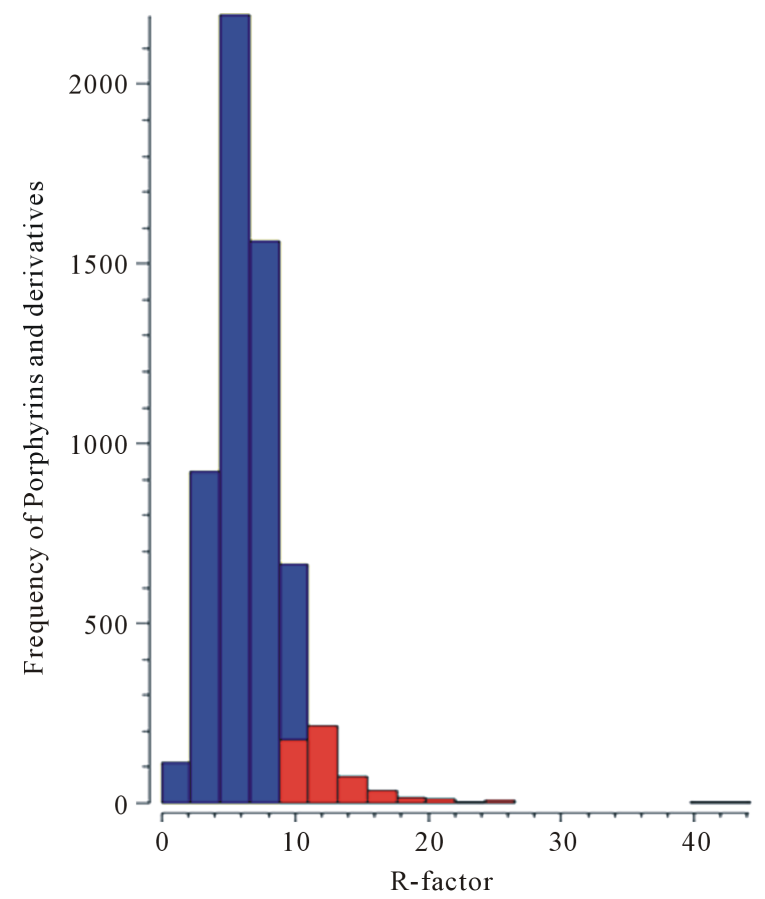

Figure 3. Distribution of porphyrins and derivatives versus R. 
Owing to this distribution the refinement parameter takes the value $\mathrm{R}=(6.682 \pm 2.848) \%$, indicating that all those structures have been solved with an accurate locating in the interval $0<\mathrm{R}<9.53$ (blue); and that also shows that most of structures were solved with high, good and medium precision. However, we can see the presence of some structures slightly accurate occurring with $10<\mathrm{R}<44.2$ (red).

The analysis of the refinement parameter also indicates that $89 \%$ of porphyrins structures of CSD have been solved with $\mathrm{R} \leq 10 \%$. All those porphyrins structures have been determined with very high, high and good precision. The $\mathrm{R}=$ Mean \pm Std. Dev value of the refinement parameter is $\mathrm{R}=(6.191 \pm 1.806) \%$, all the the structures are characterized with $4.385<\mathrm{R}<7.779$, showing the high reliability of $89 \%$ of CSD porphyrins structures.

\subsection{Geometry Analysis}

The preferred geometry of metaled meso-substuted porphyrins and derivatives is determined by assessment of twists, bond angles between opposite nitrogens and the metal in the centre of macrocycle.

\subsubsection{Twists}

For evaluating the deformations around the macrocycle two kinds of twists have been defined, in the first the meso-substitutuents-Cmeso (or H-Cmeso) acts with pyrrole's $\mathrm{C}^{\alpha}-\mathrm{C}^{\beta}$ bound that is considered as external molecular distortion caused by the meso-substuents-Cmeso and pyrrole's $\mathrm{C}^{\alpha}-\mathrm{C}^{\beta}$ bounds of the macrocycle, known as $\mathrm{C}^{\alpha}-\mathrm{C}^{\beta}-\mathrm{C}^{\text {meso }}-\mathrm{X}^{n}$ ( $n$ : number, $\mathrm{X}=$ Hmeso when unsubstituted), in the second one the meso-substitutuents-Cmeso (or H-Cmeso) acts with pyrrole's $\mathrm{C}^{\alpha}-\mathrm{N}^{n}(n=$ number) and is seen as internal molecular distortion induced by meso-substitutuents ( $n$ : number, $\mathrm{X}=$ Hmeso when unsubstituted) and pyrrole's $\mathrm{C}^{\alpha}-\mathrm{N}^{n}$, and known as $\mathrm{N}^{m}-\mathrm{C}^{\alpha}$ $\mathrm{C}^{\text {meso }}-\mathrm{X}^{n}$ (n: number).

\section{Meso-substitutuents and Hmeso External Molecular Distorsions}

Figure 4 shows the histograms of distributions of the four possible twists $T\left(C^{\beta}-C^{\alpha}-C^{\text {meso }}-X^{n}\right)\left[T\left(C^{1}-C^{5}-C^{12}-X^{31}\right)\right.$, $T\left(C^{9}-C^{11}-C^{29}-X^{32}\right), T\left(C^{16}-C^{20}-C^{26}-X^{33}\right)$ and $\left.T\left(C^{23}-C^{25}-C^{27}-X^{34}\right)\right]$ of the structures of metaled meso-substituted and Hmeso unsubstituted porphyrins caused by the meso-substuents-Cmeso or $\mathrm{H}$-Cmeso and pyrrole's $\mathrm{C}^{\alpha}-\mathrm{C}^{\beta}$ bounds of the macrocycle as previously defined. As it can be seeing easily, two kinds of porphyrins groups are presented and differentiated by blue and red colors. The meso-substituted in blue and the Hmeso unsubstituted one in red.

The twists values from the above assessments are summarized in Table 1. For each twist defined above the minimum distortion considered as planar stituation of the macrocycles, deformations and the averages of distortion are given.

Those results show that the four possible external molecular distortions caused by the meso-substuentsCmeso or H-Cmeso and pyrrole's $\mathrm{C}^{\alpha}-\mathrm{C}^{\beta}$ bounds of the macrocycle in the crystal structures occur with averages values of twist approximately equal to $6^{\circ}$. However the values of minima $\left(0^{\circ}\right)$ indicate that some of the meso-substuents-Cmeso or H-Cmeso and pyrrole's $\mathrm{C}^{\alpha}-\mathrm{C}^{\beta}$ bounds occur in a plan. It is also noticed that the highest maximum value of those twists is approximately $97^{\circ}$. Thus, the comparison of those numerical values of twists and the four histograms from Figure 4 shows that most of meso-substuents-Cmeso or H-Cmeso and pyrrole's $\mathrm{C}^{\alpha}-\mathrm{C}^{\beta}$ bounds of porphyrins crystal structures occur with twists included between $0^{\circ}-6^{\circ}$. However even though an important quantity of those structures can be distorted, the meso-substuents-Cmeso are in great quantity compared to unsubstituted. So, the optimal distortion is located between $6^{\circ}-40^{\circ}$, and the maximum value of $97^{\circ}$ is rarely observed.

This result confirm our previous study which stated that the distortion induced by the meso-substitution increase the packing of the unit cell consequently the quality or stability of crystals [7].

\section{Meso-substitutuents and Hmeso Internal Molecular Distorsions}

Figure 5 shows the histograms of distributions of the four possible twists $T\left(N^{m}-C^{\alpha}-C^{\text {meso }}-X^{n}\right)\left[T\left(N^{4}-C^{5}-C^{12}-X^{31}\right)\right.$, $\mathrm{T}\left(\mathrm{N}^{7}-\mathrm{C}^{11}-\mathrm{C}^{29}-\mathrm{X}^{32}\right), \mathrm{T}\left(\mathrm{N}^{19}-\mathrm{C}^{20}-\mathrm{C}^{26}-\mathrm{X}^{33}\right)$ and $\left.\mathrm{T}\left(\mathrm{N}^{21}-\mathrm{C}^{25}-\mathrm{C}^{27}-\mathrm{X}^{34}\right)\right]$ of the structures of metaled meso-substitutuents and Hmeso unsubstituted porphyrins induced by meso-substitutuents or $\mathrm{H}$-Cmeso and pyrrole's $\mathrm{C}^{\alpha}-\mathrm{N}^{n}$ bounds as reported above. The blue population is those substituted and red unsubstituted one.

As for the previous case of external molecular distorsions by the substitutes, the values of twists from the above distributions assessments are sum up in Table 2.

Contrarely to the results of $T\left(C^{\beta}-C^{\alpha}-C^{\text {meso }}-X^{n}\right)$ as previously described, the values obtained by evaluating $\mathrm{T}\left(\mathrm{N}^{m}-\mathrm{C}^{\alpha}-\mathrm{C}^{\text {meso }}-\mathrm{X}^{n}\right)$ seem to be opposite. The value of $180^{\circ}$ corresponds to the situation where the four atoms of $\mathrm{N}^{m}-\mathrm{C}^{\alpha}-\mathrm{C}^{\text {meso }}-\mathrm{X}^{n}$ are in the same plane. So, the maximum distortion corresponds to $91^{\circ}$ because from $180^{\circ}$ the angular gap between $91^{\circ}$ and $180^{\circ}$ is more important than any other twist. The average here $\left(175^{\circ}\right)$ is almost the 

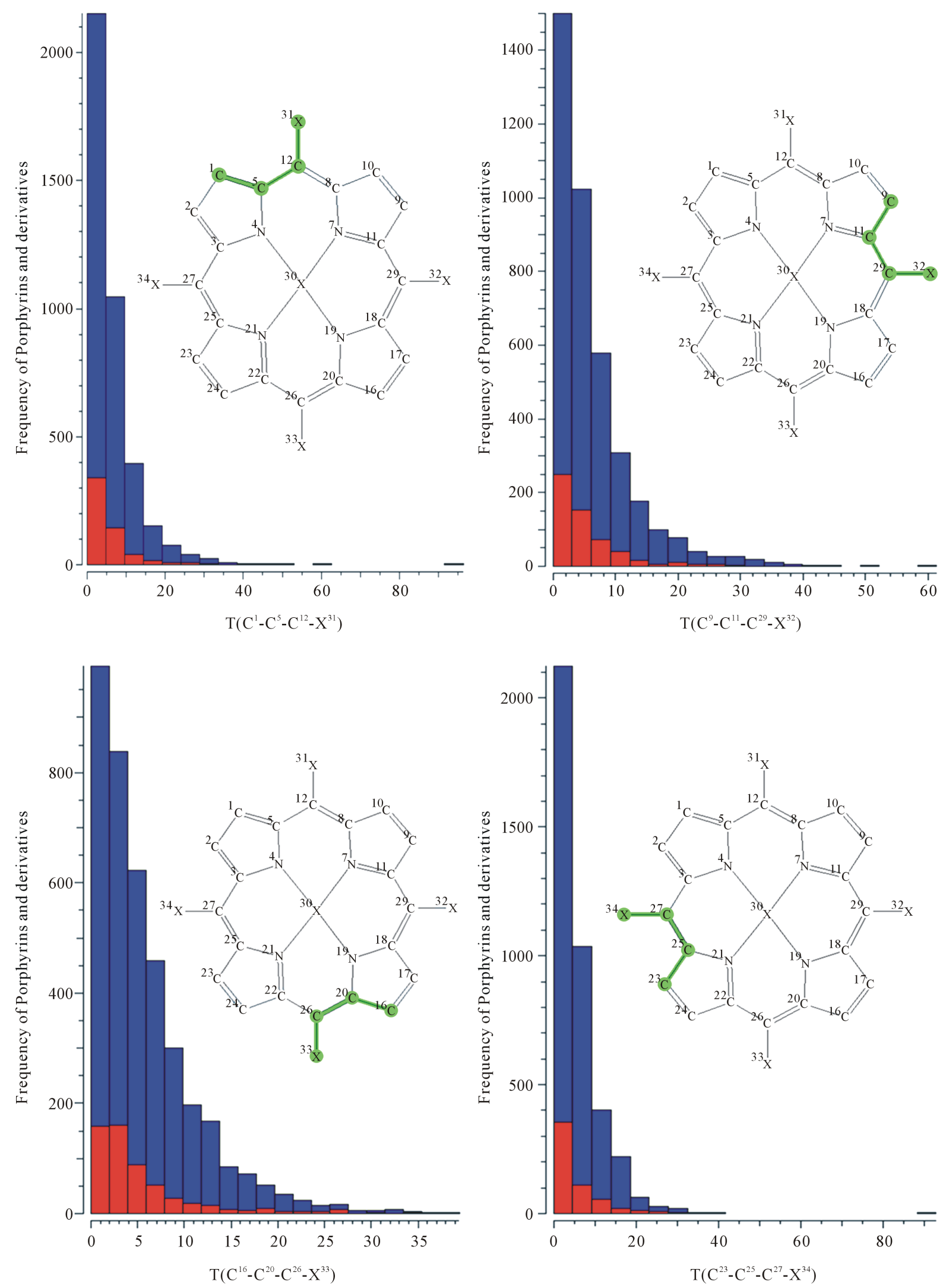

Figure 4. Distributions of $\mathrm{T}\left(\mathrm{C}^{\beta}-\mathrm{C}^{\alpha}-\mathrm{C}^{\text {meso }}-\mathrm{X}^{n}\right)$ of meso-substituted (blue) and Hmeso-unsubstituted (red) porphyrins. 
Table 1. $T\left(C^{\beta}-C^{\alpha}-C^{\text {meso }}-X^{n}\right)$ values of metaled meso-substituted porphyrins.

\begin{tabular}{rccc}
\hline & \multicolumn{3}{c}{ Distortions } \\
\cline { 2 - 4 }$\left(C^{\beta}-C^{\alpha}-C^{\text {meso }}-X^{n}\right)$ & Averages $\left(^{\circ}\right)$ & Planar $\left(^{\circ}\right)$ & Max. $\left(^{\circ}\right)$ \\
\hline $\mathrm{T}\left(C^{1}-C^{5}-C^{12}-X^{31}\right)$ & $5.871 \pm 4.153$ & 0 & 96.485 \\
$T\left(C^{9}-C^{11}-C^{29}-X^{32}\right)$ & $6.059 \pm 4.359$ & 0 & 61.487 \\
$T\left(C^{16}-C^{20}-C^{26}-X^{33}\right)$ & $5.764 \pm 3.969$ & 0 & 39.447 \\
$T\left(C^{16}-C^{20}-C^{26}-X^{33}\right)$ & $5.653 \pm 3.911$ & 0 & 93.128 \\
\hline
\end{tabular}

Table 2. $\mathrm{T}\left(\mathrm{N}^{m}-\mathrm{C}^{\alpha}-\mathrm{C}^{\text {meso }}-\mathrm{X}^{n}\right)$ values of metaled meso-substituted and unsubstituted porphyrins.

\begin{tabular}{rccc}
\hline & & Distortions & \\
\cline { 2 - 4 } $\mathrm{T}\left(\mathrm{N}^{m}-\mathrm{C}^{\alpha}-\mathrm{C}^{\mathrm{mes}}-\mathrm{X}^{n}\right)$ & Averages $\left({ }^{\circ}\right)$ & Planar $\left(^{\circ}\right)$ & Max. $\left(^{\circ}\right)$ \\
\hline $\mathrm{T}\left(\mathrm{N}^{4}-\mathrm{C}^{5}-\mathrm{C}^{12}-\mathrm{X}^{31}\right)$ & $174.842 \pm 5.603$ & 180 & 75.103 \\
$\mathrm{~T}\left(\mathrm{~N}^{7}-\mathrm{C}^{11}-\mathrm{C}^{29}-\mathrm{X}^{32}\right)$ & $174.739 \pm 5.530$ & 180 & 119.801 \\
$\mathrm{~T}\left(\mathrm{~N}^{19}-\mathrm{C}^{20}-\mathrm{C}^{26}-\mathrm{X}^{33}\right)$ & $175.137 \pm 4.754$ & 180 & 140.514 \\
$\mathrm{~T}\left(\mathrm{~N}^{21}-\mathrm{C}^{25}-\mathrm{C}^{27}-\mathrm{X}^{34}\right)$ & $175.195 \pm 4.803$ & 180 & 90.565
\end{tabular}

opposite of $6^{\circ}\left(-174^{\circ}\right)$ because here (CSD) twists were defined taking into count of absolute values. The value of $175^{\circ}$ normally is equal to $-175^{\circ}$. We can also see by comparing Figure 4 and Figure 5 that the two distributions of twists $\mathrm{T}\left(\mathrm{C}^{\beta}-\mathrm{C}^{\alpha}-\mathrm{C}^{\text {meso }}-\mathrm{X}^{n}\right)$ and $\mathrm{T}\left(\mathrm{N}^{m}-\mathrm{C}^{\alpha}-\mathrm{C}^{\text {meso }}-\mathrm{X}^{n}\right)$ are opposite values. That indicate all the twists $\mathrm{T}\left(\mathrm{N}^{m}-\mathrm{C}^{\alpha}-\right.$ $\left.\mathrm{C}^{\text {meso }}-\mathrm{X}^{n}\right)$ contrast against the distortions induced by $\mathrm{T}\left(\mathrm{C}^{\beta}-\mathrm{C}^{\alpha}-\mathrm{C}^{\text {meso }}-\mathrm{X}^{n}\right)$ to minimize distortions of macrocycles.

\subsubsection{Macrocycles Planarity}

In order to evaluate the average of the planar distortion, two kinds of twists have been defined on the plan of macrocycles. The first is $T\left(C^{\beta}-C^{\alpha}-C^{\text {meso }}-C^{\alpha}\right)$ showing the external planarity of the macrocycle, and the second one $\mathrm{N}^{n}-\mathrm{C}^{\alpha}-\mathrm{C}^{\text {meso }}-\mathrm{C}^{\alpha}$ shows the internal planarity of the macrocycle.

\section{External Planar Distorsions}

Figure 6 shows the histograms of distributions of the four possible twists $T\left(C^{\beta}-C^{\alpha}-C^{\text {meso }}-C^{\alpha}\right)\left[T\left(C^{1}-C^{5}-C^{12}-C^{8}\right)\right.$, $\mathrm{T}\left(\mathrm{C}^{9}-\mathrm{C}^{11}-\mathrm{C}^{29}-\mathrm{C}^{18}\right), \mathrm{T}\left(\mathrm{C}^{16}-\mathrm{C}^{20}-\mathrm{C}^{26}-C^{22}\right)$ and $\left.\mathrm{T}\left(\mathrm{C}^{23}-C^{25}-C^{27}-C^{3}\right)\right]$ of the structures of metaled meso-substitutuents and Hmeso unsubstituted porphyrins as reported in the top.

For all of the four distributions, the planar, deformations averages of $T\left(C^{\beta}-C^{\alpha}-C^{\text {meso }}-C^{\alpha}\right)$ are summarized in the Table 3.

One can clearly see that for $\mathrm{T}\left(\mathrm{C}^{\beta}-\mathrm{C}^{\alpha}-\mathrm{C}^{\text {meso }}-\mathrm{C}^{\alpha}\right)$ internal distortion and $\mathrm{T}\left(\mathrm{N}^{m}-\mathrm{C}^{\alpha}-\mathrm{C}^{\text {meso }}-\mathrm{X}^{n}\right)$ external one have the same distributions with similar average $\left(174^{\circ}\right.$ and $\left.175^{\circ}\right)$, respectively. However $T\left(N^{m}-C^{\alpha}-C^{\text {meso }}-X^{n}\right)$ have as maximum distortion value $91^{\circ}$ with the average of $\left(175^{\circ}\right.$ or $\left.-5^{\circ}\right)$ taking into count of absolute values, $\mathrm{T}\left(\mathrm{C}^{\beta}-\mathrm{C}^{\alpha}-\mathrm{C}^{\text {meso }}-\mathrm{C}^{\alpha}\right)$ have as maximum distortion value of $132^{\circ}$ for the same reason as previously desbcribed in Table 2 with the average of $\left(174^{\circ}\right.$ or $\left.-6^{\circ}\right)$ taking into count of absolute values. As for $T\left(N^{m}-C^{\alpha}-C^{\text {meso }}-X^{n}\right)$ the value of $180^{\circ}$ corresponds to a planar geometry. So these results indicate that even though the average of all the deformations are similar $\left(174^{\circ}\right.$ and $\left.175^{\circ}\right)$, the maxima of distortions are very different $\left(91^{\circ}=-89^{\circ}\right.$ and $132^{\circ}=$ $\left.-48^{\circ}\right)$. However, $180^{\circ}$ being the planar geometry, the distortion of $91^{\circ}$ induced by the meso-substutuents seems more important $\left(\mathrm{T}_{91}^{\circ}>\mathrm{T}_{132}^{\circ}\right.$ ). In fact $91^{\circ}$ has a more important angular gap than $132^{\circ}$ from $180^{\circ}$. This confirms again the hypothesis of our previous results [4]. Also, Figure 6 shows that for $T\left(C^{\beta}-C^{\alpha}-C^{\text {meso }}-C^{\alpha}\right)$ most of deformations cannot be under the value of $140^{\circ}$ because the populations of porphyrins are decreasing.

Internal Planar Distorsions

Figure 7 shows the histograms of distributions of the four possible twists $T\left(N^{n}-C^{\alpha}-C^{\text {meso }}-C^{\alpha}\right)\left[T\left(N^{4}-C^{5}-C^{12}-C^{8}\right)\right.$, $\mathrm{T}\left(\mathrm{N}^{7}-\mathrm{C}^{11}-\mathrm{C}^{29}-\mathrm{C}^{18}\right), \mathrm{T}\left(\mathrm{N}^{19}-\mathrm{C}^{20}-\mathrm{C}^{26}-\mathrm{C}^{22}\right)$ and $\left.\mathrm{T}\left(\mathrm{N}^{21}-\mathrm{C}^{25}-\mathrm{C}^{27}-\mathrm{C}^{3}\right)\right]$ of the structures of metaled meso-substituted and unsubstituted porphyrins that show the internal planarity of the macrocycle. 

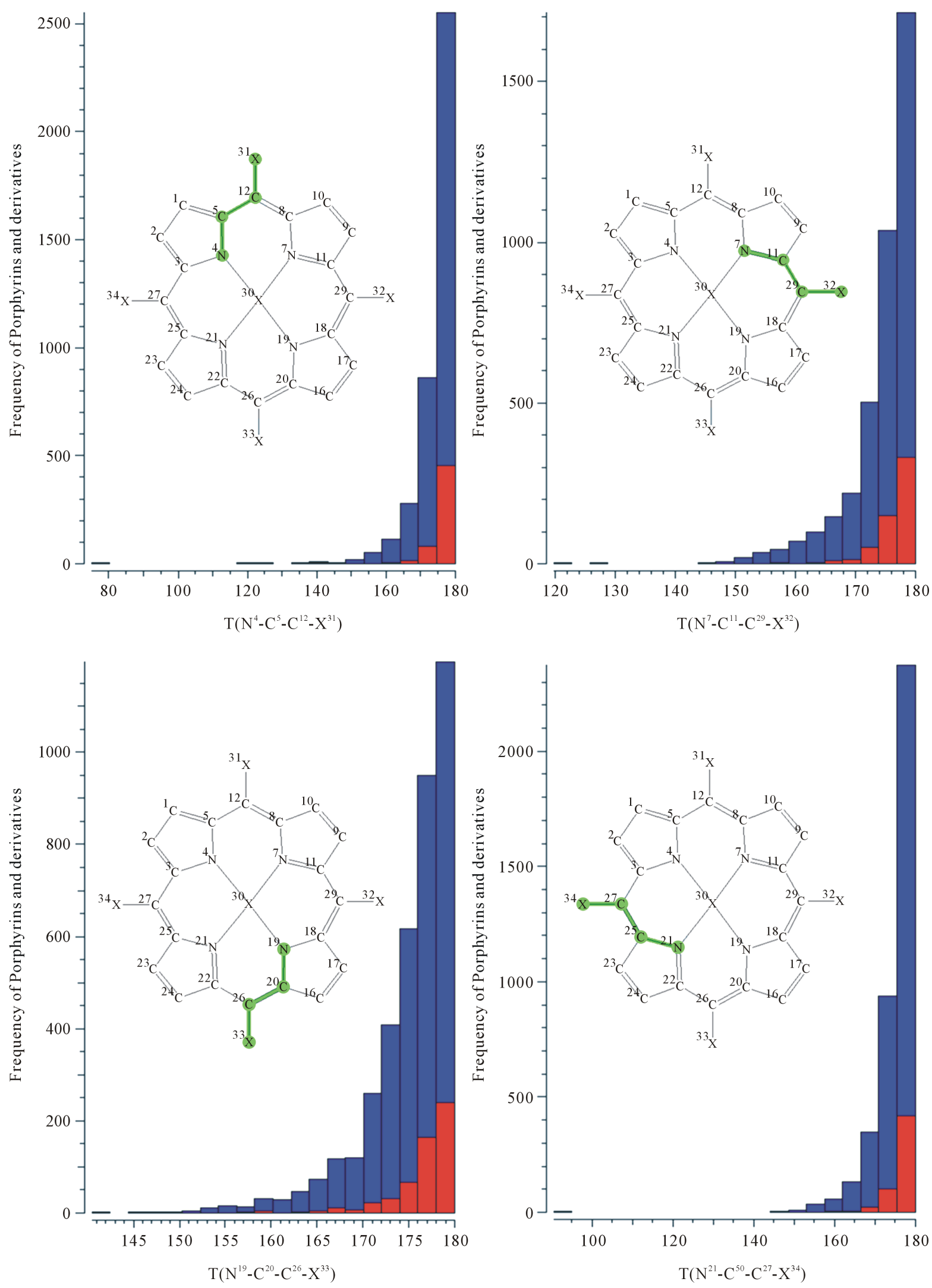

Figure 5. Distributions of $\mathrm{T}\left(\mathrm{N}^{m}-\mathrm{C}^{\alpha}-\mathrm{C}^{\text {meso }}-\mathrm{X}^{n}\right)$ of meso-substitutuents (blue) or Hmeso-unsubstituted (red) porphyrins. 

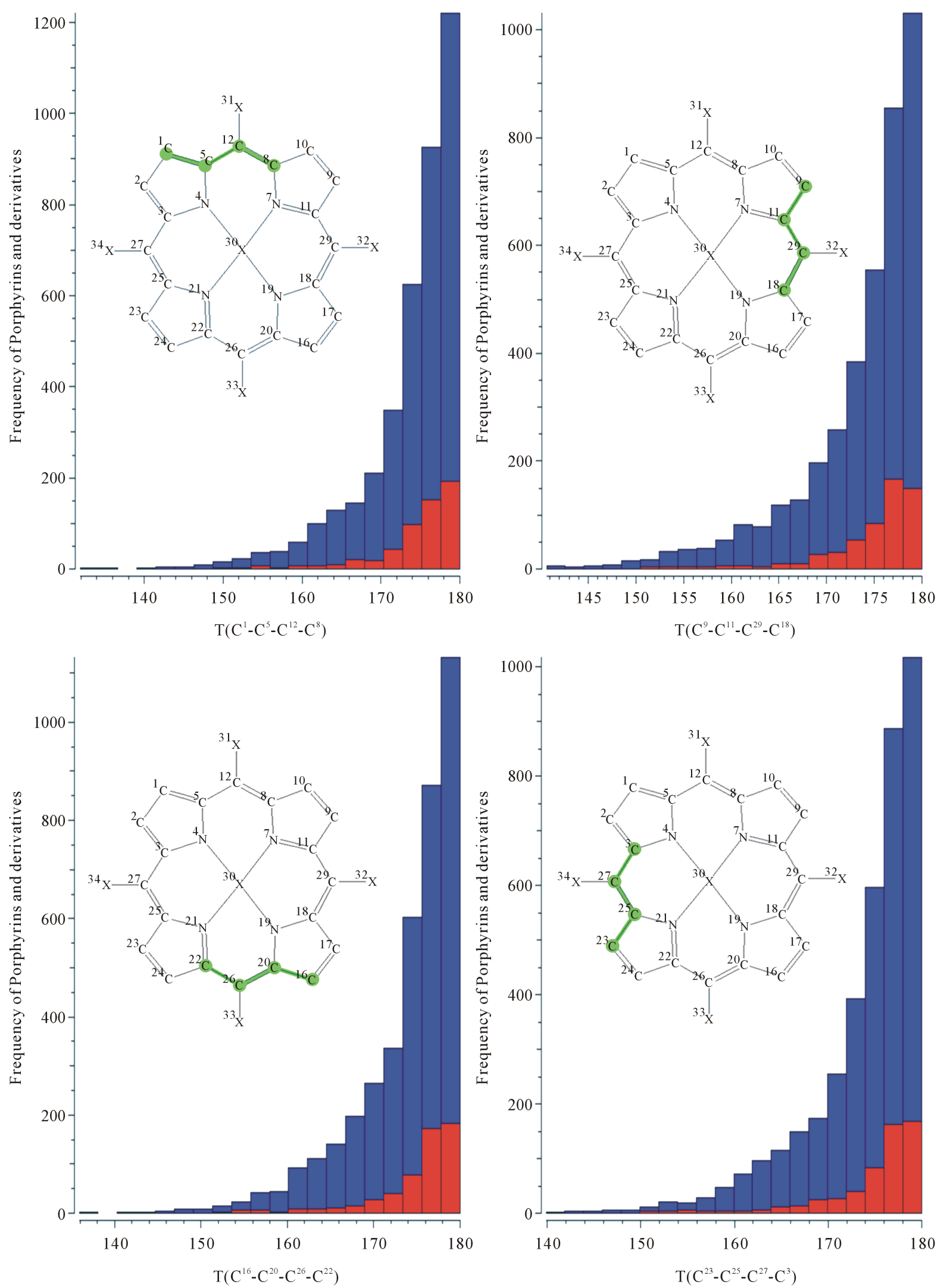

Figure 6. Distributions of $T\left(C^{\beta}-C^{\alpha}-C^{\text {meso }}-C^{\alpha}\right)$ of meso-substitutuents (blue) or Hmeso-unsubstituted (red) porphyrins. 

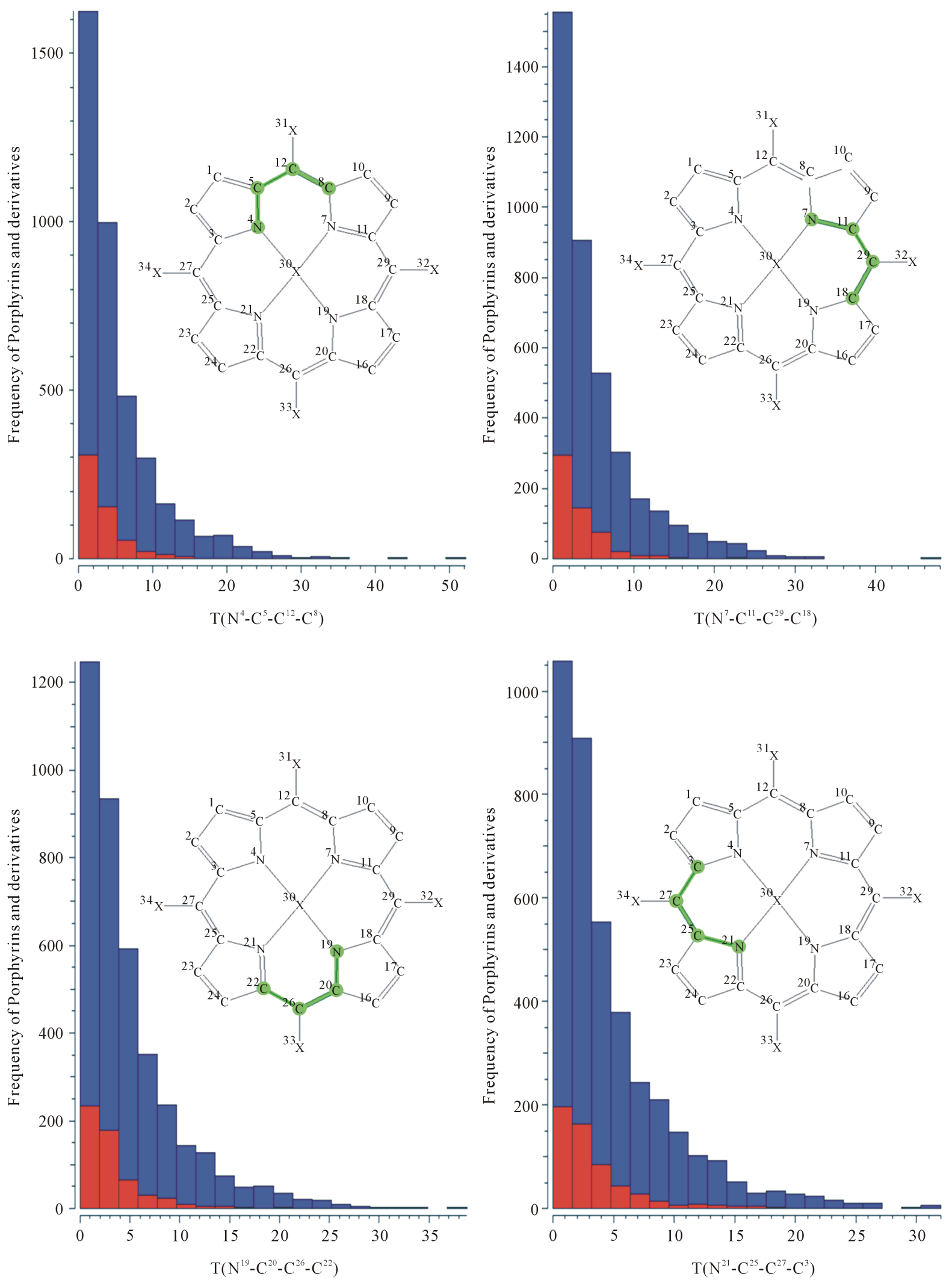

Figure 7. Distribution of the four possible twists $T\left(\mathrm{~N}^{n}-\mathrm{C}^{\alpha}-\mathrm{C}^{\text {meso }}-\mathrm{C}^{\alpha}\right)$ of meso-substitutuents (blue) or Hmeso-unsubstituted (red). 
The statistical descriptions of those distributions are sum up as average, planar and deformation in Table 4.

As for the external distorsions, one see that the external distorsions $T\left(C^{\beta}-C^{\alpha}-C^{\text {meso }}-X^{n}\right)$ and internal distortions $\mathrm{T}\left(\mathrm{N}^{n}-\mathrm{C}^{\alpha}-\mathrm{C}^{\text {meso }}-\mathrm{C}^{\alpha}\right)$ have also the same distributions with almost similar average of $6^{\circ}$ and $5^{\circ}$, respectively. Nevertheless, $\mathrm{T}\left(\mathrm{N}^{n}-\mathrm{C}^{\alpha}-\mathrm{C}^{\text {meso }}-\mathrm{C}^{\alpha}\right)$ have as maximum distortion value of $52^{\circ}$ with the average of $5^{\circ}$ meanwhile $\mathrm{T}\left(\mathrm{C}^{\beta}-\mathrm{C}^{\alpha}-\mathrm{C}^{\text {meso }}-\mathrm{X}^{n}\right)$ have as maximum distortion value of $97^{\circ}$ with the average of $6^{\circ}$. For the two distorsions $0^{\circ}$ corresponds to a planar geometry. The maxima of distorsions are different $\left(52^{\circ}\right.$ and $\left.97^{\circ}\right)$ even if there is similarity on the average $\left(6^{\circ}\right.$ and $\left.5^{\circ}\right)$. The maxima distorsions induced by the meso-substutuents seems slightly more superior $\left(\mathrm{T}_{6}^{\circ}>\mathrm{T}_{5}^{\circ}\right)$, considering the fact that $0^{\circ}$, is the planar geometry. The analysis of Figure 7 shows that for $\mathrm{T}\left(\mathrm{N}^{n}-\mathrm{C}^{\alpha}-\mathrm{C}^{\text {meso }}-\mathrm{C}^{\alpha}\right)$ most of distortions cannot be up to the value of $52^{\circ}$ because the populations of porphyrinsare decreasing.

Finally the overall distortions of metaled meso-substituted and unsubstituted porphyrins and derivatives can be summarized as follow in Table 5 .

These results shows that the maximal distortions caused by the metaled meso-substituents either in external $\left(\mathrm{T}_{97}^{\circ}>\mathrm{T}_{132}^{\circ}\right)$ or internal $\left(\mathrm{T}_{91}^{\circ}>\mathrm{T}_{52}^{\circ}\right)$ are more high than metaled meso-unsubstituted one. For the two twists $\mathrm{T}\left(\mathrm{N}^{m}-\mathrm{C}^{\alpha}-\mathrm{C}^{\text {meso }}-\mathrm{X}^{n}\right)$ and $\mathrm{T}\left(\mathrm{C}^{\beta}-\mathrm{C}^{\alpha}-\mathrm{C}^{\text {meso }}-\mathrm{C}^{\alpha}\right)$ the results have been interpreted in taking into count of absolute values given by CSD software ConQuest. These results are confirmations of our last hypothesis on the distortions of macrocycles of metaled porphyrins by meso-substituents [4].

Table 3. $T\left(C^{\beta}-C^{\alpha}-C^{\text {meso }}-C^{\alpha}\right)$ values of metaled meso-substituted and unsubstituted porphyrins.

\begin{tabular}{rccc}
\hline & \multicolumn{3}{c}{ Distortions } \\
\cline { 2 - 4 }$\left(C^{\beta}-C^{\alpha}-C^{\text {meso }}-C^{\alpha}\right)$ & Averages $\left(^{\circ}\right)$ & Planar $\left(^{\circ}\right)$ & Max. $\left(^{\circ}\right)$ \\
\hline$T\left(C^{1}-C^{5}-C^{12}-C^{8}\right)$ & $173.867 \pm 6.165$ & 180 & 75.103 \\
$T\left(C^{9}-C^{11}-C^{29}-C^{18}\right)$ & $173.717 \pm 6.361$ & 180 & 119.801 \\
$T\left(C^{16}-C^{20}-C^{26}-C^{22}\right)$ & $173.851 \pm 5.929$ & 180 & 140.514 \\
$T\left(C^{23}-C^{25}-C^{27}-C^{3}\right)$ & $173.954 \pm 5.881$ & 180 & 90.565 \\
\hline
\end{tabular}

Table 4. $\mathrm{T}\left(\mathrm{N}^{n}-\mathrm{C}^{\alpha}-\mathrm{C}^{\text {meso }}-\mathrm{C}^{\alpha}\right)$ values of metaled meso-substituted and unsubstituted porphyrins.

\begin{tabular}{rccc}
\hline & & Distortions & \\
\cline { 2 - 4 }$\left(\mathrm{N}^{\mathrm{n}}-\mathrm{C}^{\alpha}-\mathrm{C}^{\mathrm{mes}}-\mathrm{C}^{\alpha}\right)$ & Averages $\left(^{\circ}\right)$ & Planar $\left(^{\circ}\right)$ & Max. $\left(^{\circ}\right)$ \\
\hline $\mathrm{T}\left(\mathrm{N}^{4}-\mathrm{C}^{5}-\mathrm{C}^{12}-\mathrm{C}^{8}\right)$ & $4.970 \pm 3.747$ & 0 & 52.191 \\
$\mathrm{~T}\left(\mathrm{~N}^{7}-\mathrm{C}^{11}-\mathrm{C}^{29}-\mathrm{C}^{18}\right)$ & $5.096 \pm 3.942$ & 0 & 38.829 \\
$\mathrm{~T}\left(\mathrm{~N}^{19}-\mathrm{C}^{20}-\mathrm{C}^{26}-\mathrm{C}^{22}\right)$ & $4.854 \pm 3.577$ & 0 & 48.062 \\
$\mathrm{~T}\left(\mathrm{~N}^{21}-\mathrm{C}^{25}-\mathrm{C}^{27}-\mathrm{C}^{3}\right)$ & $4.778 \pm 3.541$ & 0 & 32.004 \\
\hline
\end{tabular}

Table 5. Overall distortions of metaled meso-substituted and unsubstituted porphyrins and derivatives.

\begin{tabular}{ccccc}
\hline \multirow{2}{*}{ Twists } & \multicolumn{3}{c}{ Distortions } & Directions \\
\cline { 2 - 4 } & Averages $\left(^{\circ}\right)$ & Max. distortions $\left(^{\circ}\right)$ & Planar $\left(^{\circ}\right)$ & \\
\hline $\mathrm{T}\left(\mathrm{C}^{\beta}-\mathrm{C}^{\alpha}-\mathrm{C}^{\text {meso }}-\mathrm{X}^{n}\right)$ & 6 & 97 & 0 & External \\
$\mathrm{T}\left(\mathrm{C}^{\beta}-\mathrm{C}^{\alpha}-\mathrm{C}^{\text {meso }}-\mathrm{C}^{\alpha}\right)$ & $175(-5)$ & $91(-89)$ & 180 & Internal \\
$\mathrm{T}\left(\mathrm{N}^{m}-\mathrm{C}^{\alpha}-\mathrm{C}^{\text {meso }}-\mathrm{X}^{n}\right)$ & $174(-6)$ & $132(-48)$ & 180 & External \\
$\mathrm{T}\left(\mathrm{N}^{n}-\mathrm{C}^{\alpha}-\mathrm{C}^{\text {meso }}-\mathrm{C}^{\alpha}\right)$ & 5 & 52 & 0 & Internal \\
\hline
\end{tabular}


One can more again confirm that by assessing the bond angular deformations between two opposite nitrogens with the metal at the centre.

\subsubsection{Bond Angular deformations}

Figure 8 shows the histograms of distributions of the two possible bond angular deformations in the central part of macrocycles.

The statistic descriptions of bond angular deformations are presented in Table 6.

One can notice even though distributions of Figure 5 show high peaks for planar porphyrins, many of them have significant angular deformations in the central cavity of the macrocycle, as shown quantitatively in Table 6 and visualized by two structures in 3D (Figure 9).
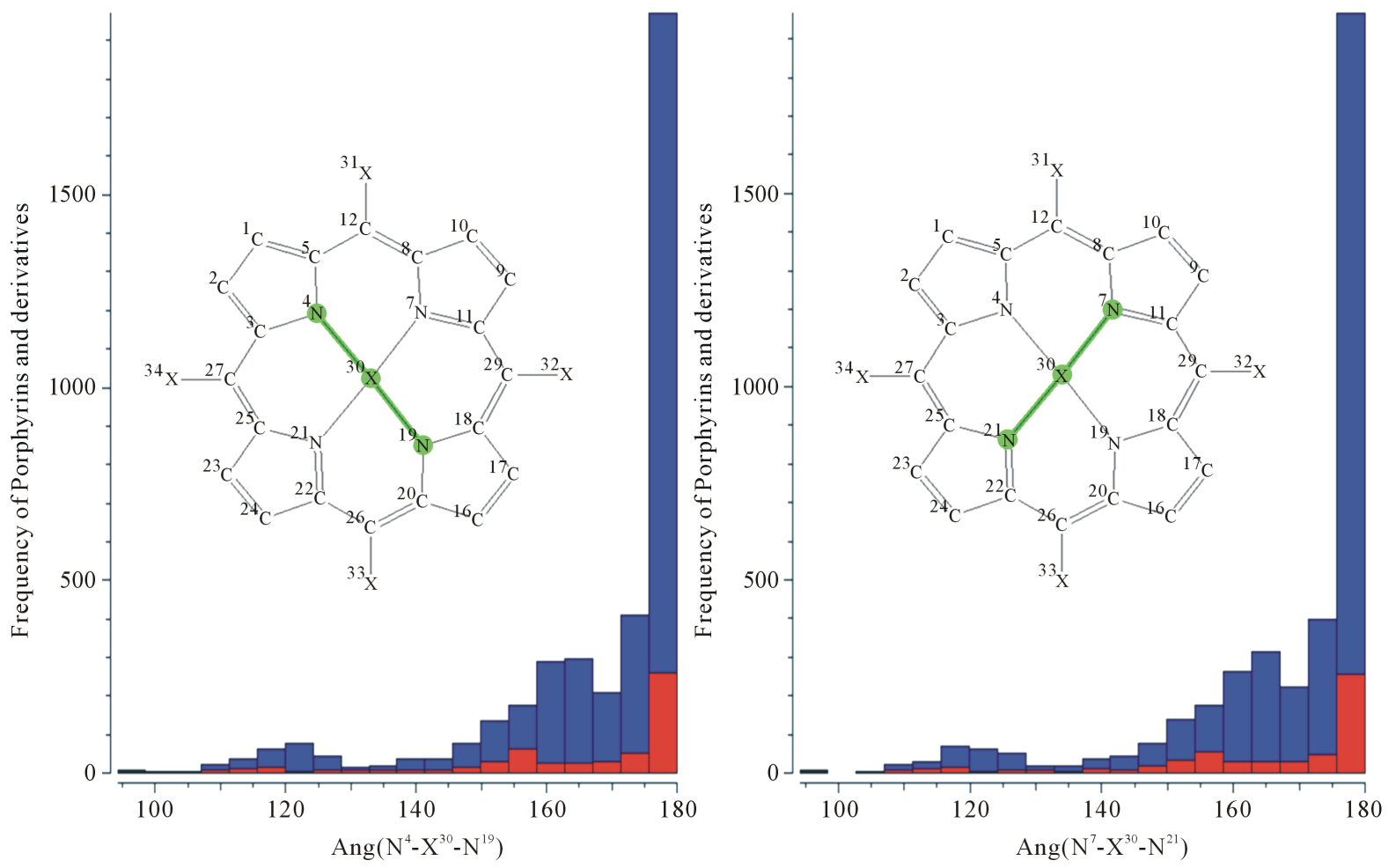

Figure 8. Distributions of the bond angular deformations of macrocycles core.
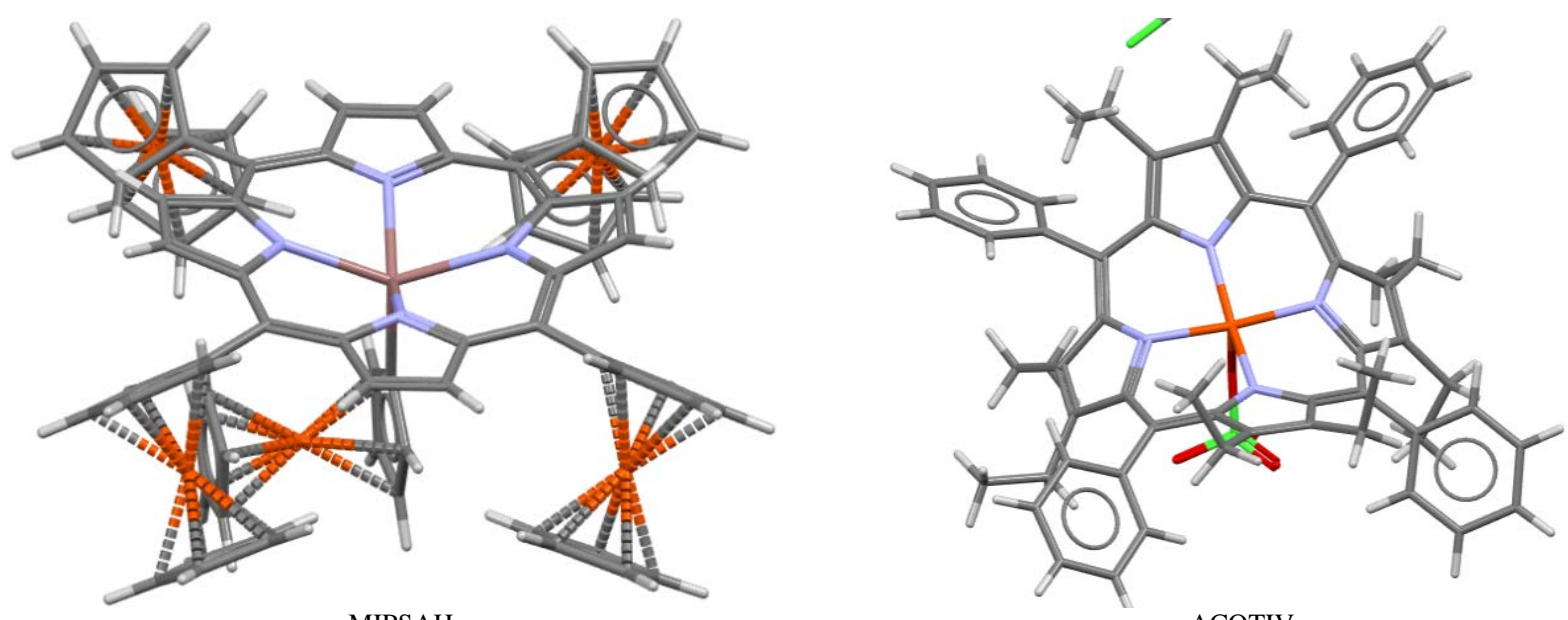

MIPSAH

ACOTIV

Figure 9. 3D visualization of the deformation of porphyrins' structures. 
Table 6. Bonds angular deformations of metaled meso-substituted and unsubstituted porphyrins and derivatives core.

\begin{tabular}{cccc}
\hline \multirow{2}{*}{ Ang $\left(\mathrm{N}^{m} \mathrm{X}^{n} \mathrm{~N}^{\circ}\right)$} & \multicolumn{3}{c}{ Deformations } \\
\cline { 2 - 4 } & Average $\left(^{\circ}\right)$ & Max. deformations $\left(^{\circ}\right)$ & Planar $\left(^{\circ}\right)$ \\
\hline Ang $\left(\mathrm{N}^{4}-\mathrm{X}^{30}-\mathrm{N}^{19}\right)$ & $168.285 \pm 16.223$ & 94.306 & 180 \\
Ang $\left(\mathrm{N}^{7}-\mathrm{X}^{30}-\mathrm{N}^{21}\right)$ & $168.227 \pm 16.227$ & 94.228 & 180 \\
\hline
\end{tabular}

The maximal of angular deformation $94^{\circ}$ (Table 6) is considered as the limit of deformation. That can be seen more easily in distribution from Figure 8. Indeed from $180^{\circ}$ to $90^{\circ}$ the populations of porphyrins are decreasing until becoming insignificant. The average of $168^{\circ}$ has to be considered as the minimum of angular deformations in the macrocycles. We have also seen in many cases that the central metal is coordinated by others substituents than the four nitrogens. Those substituents could also increase the deformations as well as distortions.

\section{Conclusion}

We have analyzed the preferred geometry of metaled meso-substituted and unsubstituted porphyrins and derivatives in their solid state (crystal structures) solved by single crystal X-ray diffraction method. The results show that most of the structures of porphyrinsin the crystal structures undergo distortions and angular deformations of their planar macrocycle. That occurs the most when hydrogens in meso are substituted, but a few populations of unsubstituted undergo the same effect. Quantitatively, the distortions and angular deformations can be as high as possible but with certain limits. The additional groups that can coordinate the central metal can also increase the distortions and bond angular deformations. The quantitative analysis of the additional groups coordinating the central metals is in process.

\section{Acknowledgements}

The authors are grateful to the "Laboratoire de chimie physique structural” lead by Professor Z.G. Yav and to Cambridge Crystallographic Data Centre for the materials support, the series of seminars and workshops on the use of the CSD System delivered at the University of Kinshasa.

\section{References}

[1] Baberschke, K. (2009) Magnetic Switching of Fe-Porphyrin Molecules Adsorbed on Surfaces: An XAFS and XMCD Study. Journal of Physics: Conference Series, 190, Article ID: 012012. http://dx.doi.org/10.1088/1742-6596/190/1/012012

[2] Winters, M.U., Karnbratt, J., Eng, M., Wilson, C.J., Anderson, H.L. and Albinsson, B. (2007) Photophysics of a Butadiyne-Linked Porphyrin Dimer: Influence of Conformational Flexibility in the Ground and First Singlet Excited State. The Journal of Physical Chemistry C, 111, 7192-7199. http://dx.doi.org/10.1021/jp0683519

[3] Shelnutt, J.A., Song, X.Z., Ma, J.G., Jia, S.L., Jentzen, W. and Medforth, C.J. (1998) Nonplanar Porphyrins and Their Significance in Proteins. Chemical Society Reviews, 27, 31-42. http://dx.doi.org/10.1039/a827031z

[4] Adilov, S. and Thalladi, V.R. (2007) Layered Porphyrin Coordination Polymers Based on Zinc-Nitro Recognition: Reversible Intercalation of Nitrobenzene. Crystal Growth \& Design, 7, 481-484. http://dx.doi.org/10.1021/cg0607957

[5] Senge, M.O., Ryan, A.A., Letchford, K.A., MacGowan, S.A. and Mielke, T. (2014) Chlorophylls, Symmetry, Chirality, and Photosynthesis. Symmetry, 6, 781-843. http://dx.doi.org/10.3390/sym6030781

[6] Słota, R., Broda, M.A., Dyrda, G., Ejsmont, K. and Mele, G. (2011) Structural and Molecular Characterization of Meso-Substituted Zinc Porphyrins: A DFT Supported Study. Molecules, 16, 9957-9971. http://dx.doi.org/10.3390/molecules16129957

[7] Tsalu, P.V., Nsimba, B.M., Mwanangombo, D.T., Tshilanda, D.D., Mpiana, P.T. and Yav, Z.G. (2015) Correlation between Structure and Crystallization of Porphyrins and Derivatives. Journal of Physical and Chemical Sciences, 3 I4. http://dx.doi.org/10.15297/JPCS.V3I4.03

[8] Barbee, J. and Kuznetsov, A.E. (2012) Revealing Substituent Effects on the Electronic Structure and Planarity of NiPorphyrins. Computational and Theoretical Chemistry, 981, 73-85. http://dx.doi.org/10.1016/j.comptc.2011.11.049

[9] Nsimba, B.M., Tsalu, P.V., Mwanangombo, D.T., Atibu, E.K., Tshibangu, D.S.T., Kayembe, K., Basosila, N.L., Mi- 
higo, S.O. and Mpiana, P.T. (2015) Electron Withdrawing Groups and Steric Effects on the Methanogenic Toxicity. American Chemical Science Journal, 10(1), Article No. ACSJ.21375, 1-8. http://dx.doi.org/10.9734/ACSJ/2016/21375

[10] Nsimba, B.M., Kayembe, K., Basosila, N.L., Mihigo, S.O., Mbala, B.M., Mulaji, C.K., Tsalu, P.V., Mvingu, B.K. and Mpiana, P.T. (2015) Electronic Effects of Substituted Aromatic Ring on the Methanogenic Toxicity. Journal of Physical and Chemical Sciences, 3I2. http://dx.doi.org/10.15297/JPCS.V3I2.02

[11] Bhyrappa, P. and Arunkumar, C. (2010) Structural and Electrochemical Properties of $\beta$-Tetrabromo-mesotetrakis (4-alkyloxyphenyl)porphyrins and Their Metal Complexes. Journal of Chemical Sciences, 122, 233-238. http://dx.doi.org/10.1007/s12039-010-0027-6

[12] Degtyarenko, I., Biarnes, X., Nieminen, R.M. and Rovira, C. (2008) Density-Functional Molecular Dynamics Studies of Biologically Relevant Iron and Cobalt Complexes with Macrocyclic Ligands. Coordination Chemistry Reviews, 252, 1497-1513. http://dx.doi.org/10.1016/j.ccr.2007.10.022

[13] Chaudhary, A., Patra, R. and Rath, S.P. (2011) Synthesis, Structure and Properties of High-Spin Fe(III) Porphyrin with Non-Equivalent Axial Ligands: Implications for the Hemoproteins. Indian Journal of Chemistry, 50A, 432-437.

[14] Shelnutt, J.A., Song, X.Z., Ma, J.G., Jia, S.L., Jentzen, W. and Medforth, C.J. (1998) Nonplanar Porphyrins and Their Significance in Proteins. Chemical Society Reviews, 27, 31-42. http://dx.doi.org/10.1039/a827031z

[15] Senge, M.O., Ema, T. and Smith, K.M. (1995) Crystal Structure of a Remarkably Ruff Led Nonplanar Porphyrin (Pyridine)[5,10,15,20-tetra (fert-butyl)porphyrinato]zinc(II) . Journal of the Chemical Society, Chemical Communications, 1995, 733-734.

[16] Senge, M.O., Medforth, C.J., Forsyth, T.P., Lee, D.A., Olmstead, M.M., Jentzen, W., Pandey, R.K., Shelnutt, J.A. and Smith, K.M. (1997) Comparative Analysis of the Conformations of Symmetrically and Asymmetrically Decaand Undecasubstituted Porphyrins Bearing Meso-Alkyl or -Aryl Groups. Inorganic Chemistry, 36, 1149-1163. http://dx.doi.org/10.1021/ic961156w

[17] Senge, M.O. (2011) (5-Tert-butylporphyrinato)copper(II), a Nonplanar Porphyrin with Only One Sterically Demanding Meso Residue. Acta Crystallographica, C67, m39-m42. http://dx.doi.org/10.1107/S0108270111000904

[18] Drain, C.M., Kirmaier, C., Medforth, C.J., Nurco, D.J., Smith, K.M. and Holten, D. (1996) Dynamic Photophysical Properties of Conformationally Distorted Nickel Porphyrins. Nickel(II) Dodecaphenylporphyrin. The Journal of Physical Chemistry, 100, 11984-11993. http://dx.doi.org/10.1021/jp960735j

[19] Sun, Z.C., She, Y.B., Zhou, Y., Song, X.F. and Li, K. (2011) Synthesis, Characterization and Spectral Properties of Substituted Tetraphenylporphyrin Iron Chloride Complexes. Molecules, 16, 2960-2970. http://dx.doi.org/10.3390/molecules16042960

[20] Bhyrappa, P., Wilson, S.R. and Suslick, K.S. (1997) Hydrogen-Bonded Porphyrinic Solids: Supramolecular Networks of Octahydroxy Porphyrins. Journal of the American Chemical Society, 119, 8492-8502. http://dx.doi.org/10.1021/ja971093w

[21] Allen, F.H. (2002) The Cambridge Structural Database: A Quarter of a Million Crystal Structures and Rising. Acta Crystallographica Section B, B58, 380-388. http://dx.doi.org/10.1107/S0108768102003890

[22] Sykes, R.A., McCabe, P., Allen, F.H., Battle, G.M., Ian, J.B. and Wood, P.A. (2011) New Software for Statistical Analysis of Cambridge Structural Database Data. Journal of Applied Crystallography, 44, 882-886. http://dx.doi.org/10.1107/S0021889811014622

[23] Battle, G.M., Allen, F.H. and Ferrence, G.M. (2011) Teaching Three-Dimensional Structural Chemistry Using Crystal Structure Databases. 3. The Cambridge Structural Database System: Information Content and Access Software in Educational Applications. Journal of Chemical Education, 88, 886-890. http://dx.doi.org/10.1021/ed1011019

[24] Ian, R.T., Ian, J.B., Cole, J.C., Macrae, C.F., Pidcock, E. and Wood, P.A. (2010) WebCSD: The Online Portal to the Cambridge Structural Database. Journal of Applied Crystallography, 43, 362-366. http://dx.doi.org/10.1107/S0021889810000452

[25] Battle, G.M., Ferrence, G.M. and Allen, F.H. (2010) Applications of the Cambridge Structural Database in Chemical Education. Journal of Applied Crystallography, 43, 1208-1223. http://dx.doi.org/10.1107/S0021889810024155

[26] Battle, G.M., Allen, F.H. and Ferrence, G.M. (2010) Teaching Three-Dimensional Structural Chemistry Using Crystal Structure Databases. 2. Teaching Units That Utilize an Interactive Web-Accessible Subset of the Cambridge Structural Database. Journal of Chemical Education, 87, 813-818. http://dx.doi.org/10.1021/ed100257t

[27] Battle, G.M., Allen, F.H. and Ferrence, G.M. (2011) Teaching Three-Dimensional Structural Chemistry Using Crystal Structure Databases. 4. Examples of Discovery-Based Learning Using the Complete Cambridge Structural Database. Journal of Chemical Education, 88, 891-897. http://dx.doi.org/10.1021/ed1011025

[28] Battle, G.M., Allen, F.H. and Ferrence, G.M. (2010) Teaching Three-Dimensional Structural Chemistry Using Crystal Structure Databases. 1. An Interactive Web-Accessible Teaching Subset of the Cambridge Structural Database. Journal 
of Chemical Education, 87, 809-812. http://dx.doi.org/10.1021/ed100256k

[29] Battle, G.M. and Allen, F.H. (2012) Learning about Intermolecular Interactions from the Cambridge Structural Database. Journal of Chemical Education, 89, 38-44. http://dx.doi.org/10.1021/ed200139t

[30] Egli, M. (2010) Diffraction Techniques in Structural Biology. Overview for Unit 7 "Biophysical Analysis of Nucleic Acids”. Current Protocols in Nucleic Acid Chemistry, 41, 7.13.1-7.13.35. http://dx.doi.org/10.1002/0471142700.nc0713s41 